PRZEGLĄD BIBLIOTECZNY 2020 z. 2

PL ISSN 0033-202X

\title{
MAGDALENA WÓJCIK
}

Instytut Studiów Informacyjnych

Uniwersytet Jagielloński

e-mail: magda.wojcik@uj.edu.pl

ORCID 0000-0001-5059-858X

\section{UNPLUGGED - CO-WORKING - CO-LIVING - EMERGING ADULTHOOD? NOWE ZJAWISKA SPOŁECZNE A BIBLIOTEKI}

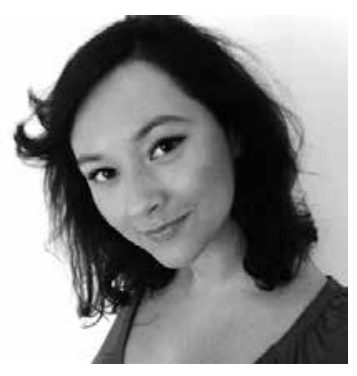

Dr hab. Magdalena Wójcik, adiunkt w Instytucie Studiów Informacyjnych Uniwersytetu Jagiellońskiego. Jej zainteresowania badawcze obejmują problematykę wykorzystania najnowszych technologii informacyjnokomunikacyjnych w usługach instytucji książki. Najważniejsze publikacje to: Rozszerzona rzeczywistość w ustugach informacyjnych bibliotek (Kraków, 2018), Web 2.0 w działalności usługowej instytucji książki (Kraków, 2013), Internet of Things - potential for libraries, „, Library Hi Tech" 2016, vol. 34, issue 2, p. 404-420 oraz Holograms in libraries - the potential for education, promotion and services, „Library Hi Tech” 2018, vol. 36, issue 1, pp. 18-28.

SŁOWA KLUCZOWE: Usługi biblioteczne. Użytkownicy bibliotek. Zadania bibliotek. Zjawiska społeczne.

ABSTRAKT: Teza/cel - Przedmiot artykułu stanowią wybrane nowe zjawiska społeczne, które według American Library Association (ALA) mogą mieć największy wpływ na działania i przyszłość bibliotek. Celem jest omówienie potencjalnych konsekwencji wytypowanych zjawisk dla usług bibliotecznych. Metoda - Zastosowano metodę analizy i krytyki piśmiennictwa. W oparciu o materiały publikowane w serwisie WWW ALA oraz wyszukiwanie prowadzone w katalogu Biblioteki Narodowej i katalogu WorldCat, bazie abstraktowej LISTA, repozytorium ELIS oraz wybranych bazach wielodziedzinowych określono stan 
badań nad nowymi zjawiskami społecznymi z perspektywy bibliotekoznawczej. Pod uwagę wzięto wyłącznie prace opublikowane w języku polskim i angielskim w latach 2010-2018. Wyniki - Przeprowadzona analiza piśmiennictwa pozwala stwierdzić, że wskazane przez ALA trendy społeczne nie są często omawiane na gruncie bibliotekoznawstwa. $\mathrm{W}$ oparciu o materiały publikowane $\mathrm{w}$ serwisie WWW ALA można jednak sądzić, że wskazane trendy społeczne mogą mieć istotny wpływ na oczekiwania użytkowników względem bibliotek. Wnioski - Przeprowadzona analiza pozwala wysnuć wniosek, że omówione trendy społeczne mogą wpływać na potrzeby i przyzwyczajenia użytkowników, a tym samym na zakres i sposób świadczenia usług bibliotecznych. Biblioteki jako instytucje usługowe działające $w$ przestrzeni społecznej muszą monitorować nowe zjawiska kulturowe, ekonomiczne czy technologiczne i dostosowywać swój sposób działania do aktualnej sytuacji.

\section{WSTĘP}

Biblioteka, jak każda instytucja usługowa, podlega wpływom społecznym, ekonomicznym oraz technologicznym. Jak zaznacza Elżbieta Kuźma: „W dobie globalnej walki o klienta, kwestia zachęcenia czytelnika do skorzystania z usług oferowanych przez biblioteki staje się takim samym problemem, jak sprzedaż produktu na wolnym rynku" (Kuźma, 2015, s. 318). Biblioteki, by utrzymać się na konkurencyjnym rynku usług informacyjnych, stale dostosowują swoje działania do aktualnej sytuacji. W rezultacie, tak jak zmieniają się potrzeby i przyzwyczajenia użytkowników, tak zmienia się zakres i sposoby świadczenia usług bibliotecznych. Choć misja biblioteki i podstawowy kanon jej usług związany z organizacją procesu pośredniczenia między użytkownikiem a zasobami jest stały (Wojciechowski, 2014, s. 53), to jednak zakres oferty bibliotecznej - szczególnie usługowej - ulega ciagłej modyfikacji. Pozostaje odpowiedzieć na pytanie, czy obecność zjawisk społecznych identyfikowanych jako istotne przez bibliotekarskie organizacje profesjonalne znajduje odbicie w literaturze przedmiotu i w jaki sposób zjawiska te mogą w praktyce wpływać na sposoby świadczenia nowoczesnych usług bibliotecznych.

\section{PRZEDMIOT I CEL}

Przedmiot artykułu stanowią nowe zjawiska społeczne, które mogą mieć istotny wpływ na działania bibliotek. Celem jest omówienie potencjalnych konsekwencji wytypowanych zjawisk dla usług bibliotecznych. Pod uwage wzięto trendy, takie jak: unplugged culture, co-working, co-living i emerging adulthood, wskazane w raporcie American Library Association jako jedne ze zjawisk, które mogą mieć największy wpływ na działania bibliotek (American..., 2018). Do celów szczegółowych można zaliczyć: 
- scharakteryzowanie głównych cech wybranych zjawisk społecznych, takich jak: unplugged culture, co-working, co-living i emerging adulthood,

- określenie na podstawie analizy literatury profesjonalnej oraz materiałów publikowanych przez kluczowe stowarzyszenia bibliotekarskie potencjalnego wpływu opisanych zjawisk na zakres i sposoby świadczenia usług bibliotecznych.

\section{KLUCZOWE POJĘCIA}

Przed przystąpieniem do dalszych rozważań wyjaśnienia wymagają kluczowe pojęcia użyte $\mathrm{w}$ tekście. Pierwszym z nich jest kultura unplugged, nurt definiowany za ALA, jako potrzeba odłączenia się od ciągłego napływu informacji i bodźców związanych z korzystaniem z multimedialnych, wysoce interaktywnych środowisk komunikacyjnych, takich jak media społecznościowe (American..., 2018). Co ciekawe, zjawisko to dotyczy nie tyle osób mniej zaawansowanych technologicznie czy starszych, które mogłyby czuć się przyłłoczone natłokiem informacji, ale często osób młodych, bardzo aktywnych $\mathrm{w}$ środowisku elektronicznym i biegłych w posługiwaniu się nowymi technologiami. Do takich grup użytkowników mogą należeć m.in.: przedstawiciele branży kreatywnej - blogerzy, vlogerzy, projektanci, a także dziennikarze czy reprezentanci branży technologicznej. Przedstawiciele wymienionych grup okazjonalnie odczuwają znużenie ciągłą komunikacją elektroniczną i koniecznością nieustannego śledzenia nowych informacji publikowanych w sieci. Nie moga przy tym - i nie chcą - rezygnować z nowych narzędzi informacyjno-komunikacyjnych, ale rozumieją konieczność rozsądnego z nich korzystania. Istotne jest zatem wyraźne zaznaczenie, że nurt unplugged nie oznacza rezygnacji ze zdobyczy nowych technologii, a jedynie zakłada racjonalne i zbalansowane korzystanie $z$ urządzeń elektronicznych, internetu czy mediów społecznościowych i przeprowadzanie okazjonalnego „detoksu” poprzez dobrowolne powstrzymanie się od korzystania z wybranych narzędzi (najczęściej na krótki czas np. 24 h, weekend itp.).

Kolejnym ciekawym pojęciem jest współdzielenie przestrzeni życia czy pracy z innymi ludźmi - często nieznajomymi - opisywane w literaturze przedmiotu jako co-working i co-living. Sytuacja ekonomiczna zmusza współcześnie wiele osób, szczególnie młodych, rozpoczynających karierę zawodowa, do współdzielenia przestrzeni życia i pracy z innymi. Niskie zarobki na stanowiskach stażowych typu entry level połączone z wysokimi cenami mieszkań i lokali biurowych - szczególnie w dużych miastach sprawiaja, że wspólne mieszkanie czy wynajmowanie przestrzeni pracy grupowej typu co-work staje się koniecznością. Wśród osób znajdujących się $\mathrm{w}$ lepszej sytuacji finansowej modne staje się z kolei mieszkanie we 
wspólnotach typu co-housing, w których indywidualna przestrzeń jest łączona $\mathrm{z}$ elementami przestrzeni wspólnej np. siłowni, restauracji, parku czy przestrzeni biurowej, co pomaga tworzyć zintegrowaną grupę mieszkańców (Chimczak, 2017).

Ostatnie z omawianych zagadnień, zjawisko emerging adulthood można zdefiniować wg ALA jako wydłużenie się okresu, w którym młodzi ludzie decydują się na rozpoczęcie samodzielnego życia i założenie rodziny (American..., 2018). Przedstawiciele generacji Y i tzw. milenialsi poświęcają więcej czasu na zdobycie wykształcenia, często zmieniając kilkakrotnie kierunki studiów, próbują wielu prac na poziomie entry level, starając się ustalić własne zainteresowania i ambicje zawodowe, co sprawia, że często później uzyskują niezależność finansową i podejmują decyzję o opuszczeniu domu rodzinnego (Schwartz, 2017). Cechą charakteryzującą tę grupę społeczną jest chęć poszukiwania pomysłu na życie oraz odnajdowanie i rozwijanie własnych pasji.

\section{METODA}

Zastosowano metodę analizy i krytyki piśmiennictwa. W oparciu o wyszukiwanie prowadzone w katalogu Biblioteki Narodowej i katalogu WorldCat, bazie abstraktowej LISTA, repozytorium ELIS oraz wybranych bazach wielodziedzinowych (przeszukanych za pomocą Google Scholar) określono stan badań. Pod uwagę wzięto wyłącznie prace opublikowane w języku polskim i angielskim w latach 2010-2018.

Przeprowadzona analiza pozwoliła stwierdzić, że wskazywane przez ALA trendy społeczne są rzadko przedmiotem refleksji na gruncie bibliotekoznawstwa.

Koncepcja unplugged była na przykład poruszana w wydawanym przez Association for Library Service to Children czasopiśmie "Children and Libraries” w kontekście porównania procesów lektury książki tradycyjnej i elektronicznej określanych jako unplugged i plugged reading (McVicker, 2017). W artykule brak jednak bezpośrednich odniesień do problematyki usług bibliotecznych. Niezwykle istotny - z punktu widzenia przedmiotu rozważań w tym artykule - jest tekst An Unplugged Space. Would your users value a gadget-free quiet zone in your library? (Wakaruk \& Truitt, 2011), w którym autorzy stawiają pytanie o zasadność tworzenia w bibliotekach miejsc sprzyjających odłączeniu się od technologicznych gadżetów, nie dając na nie jednak klarownej odpowiedzi. Ciekawą perspektywę pokazuje także artykuł A quiet place for student veterans, w którym tworzenie $\mathrm{w}$ bibliotece miejsc pozbawionych urządzeń elektronicznych i innych absorbujących bodźców może pomóc $\mathrm{w}$ adaptacji studentom borykającym się z problemami psychicznymi i emocjonalnymi, $w$ tym weteranom powracającym na studia po odbyciu służby wojskowej (Hollingsworth, 
2015). W artykule trudno jednak znaleźć wskazówki dotyczące wdrażania tego rodzaju rozwiązań w innych typach bibliotek.

Przytoczone przykłady pokazuja, że problematyka unplugged jest niekiedy poruszana w literaturze, ale bardzo rzadko i w sposób niedający odpowiedzi na pytania o wpływ tej koncepcji na działania bibliotek.

Problematyka współdzielenia przestrzeni, szczególnie w kontekście środowiska nauki czy pracy, była poruszana w bibliotekoznawczej literaturze przedmiotu nieco częściej, szczególnie w kontekście działań podejmowanych przez biblioteki akademickie. Przykładem może być tekst Co-working and innovation: new concepts for academic libraries and learning centres (Schopfel, Roche \& Hubert, 2015), czy tekst A coworking project in the campus library: supporting and modeling entrepreneurial activity in the academic library (Lumley, 2014), w których zaprezentowano potencjał bibliotek uczelnianych jako co-workingowych przestrzeni nauki i pracy. Trudno jednak znaleźć analogiczne prace, w których odnoszono by się np. do roli bibliotek publicznych w tym zakresie.

Zjawisko emerging adulthood było najrzadziej omawiane. Wprawdzie wątki związane z pojawianiem się nowych grup użytkowników czy zacieraniem granic między poszczególnymi grupami (szczególnie wiekowymi) pojawiają się okazjonalnie $\mathrm{w}$ piśmiennictwie głównie $\mathrm{z}$ zakresu diagnozowania potrzeb użytkowników, to jednak pojęcie emerging adulthood nie jest używane.

Podsumowując można stwierdzić, że zarówno w polskiej, jak i anglojęzycznej literaturze przedmiotu wątki sygnalizowane przez ALA jako istotne dla rozwoju bibliotek są rzadko poruszane. Ta luka w piśmiennictwie powinna zostać zapełniona.

\section{UNPLUGGED A BIBLIOTEKI}

Nie ulega wątpliwości, że nowe narzędzia informacyjno-komunikacyjne odgrywają istotną rolę w życiu wielu grup użytkowników - szczególnie osób młodych, uczących się czy aktywnych zawodowo. Biblioteki wychodząc naprzeciw tym trendom rozwijają swoją ofertę usług elektronicznych i inwestują w nowe technologie (Wójcik, 2016). Przykładem może być komputeryzacja bibliotek, inwestowanie w elektroniczne katalogi i bazy danych, świadczenie usług online czy oferowanie usług za pośrednictwem aplikacji mobilnych, a także wykorzystywanie nowych technologii np. wirtualnej czy rozszerzonej rzeczywistości w działaniach promocyjnych i edukacyjnych (Gmiterek \& Kotuła, 2017; Wójcik, 2013). W tym kontekście ciekawym zjawiskiem społecznym jest rozwój kultury unplugged. Zjawisko to może mieć ciekawe konsekwencje dla bibliotek, sprzyjając na przykład promocji książki tradycyjnej jako alternatywnego sposobu spędzania wolnego czasu, który nie wymaga korzystania 
z urządzeń elektronicznych. W tym kontekście warto się zastanowić nad promowaniem standardowych usług bibliotecznych polegających np. na udostępnieniu miejsca do spokojnej lektury w sposób nawiązujący do modnego nurtu unplugged. Według ALA istotna jest zmiana na poziomie językowym - zamiast reklamować przestrzenie cichej nauki, lepiej promować unplug zones lub digital escape spaces (American..., 2018). Warto byłoby opracować polskie odpowiedniki tego typu nazewnictwa i wykorzystywać je w działaniach marketingowych bibliotek.

W działaniach promujących bibliotekę jako „odłączone miejsce” (ang. unplugged space) istotne jest jednak zachowanie równowagi między pokazaniem biblioteki jako miejsca, w którym można ciekawie odpoczywać bez elektroniki, ciesząc się elementami tradycyjnej kultury książki, nie wpadając jednocześnie w negatywny stereotyp biblioteki jako archaicznego miejsca pozbawionego nowoczesnych rozwiązań.

Warto również zauważyć, że tworzenie w bibliotece przestrzeni pozbawionych urządzeń elektronicznych, sprzyjających wyciszeniu i refleksji, może nie tylko służyć użytkownikom ze środowisk kreatywnych i technologicznych, zmęczonych ciągłym korzystaniem z nowych mediów, ale także może stać się elementem oferty usługowej dla użytkowników niepełnosprawnych borykających się z problemami poznawczymi, psychicznymi czy emocjonalnymi (Hollingsworth, 2015), np. dla osób ze spektrum autyzmu, które szczególnie silnie reagują na niektóre bodźce płynące $\mathrm{z}$ otoczenia.

\section{CO-WORKING I CO-LIVING A BIBLIOTEKI}

Rozwój zjawisk co-working i co-living generuje szerokie konsekwencje społeczne i może mieć wpływ na oczekiwania użytkowników względem bibliotek. Użytkownicy przyzwyczajeni do współdzielenia przestrzeni z innymi z jednej strony cenią stymulujące środowisko pracy grupowej i towarzyskie aspekty współdzielenia przestrzeni mieszkania czy pracy (ALA...2018), z drugiej - mogą odczuwać zmęczenie przymusowym, stałym kontaktem $\mathrm{z}$ innymi osobami. $\mathrm{W}$ tym kontekście biblioteka $\mathrm{z}$ jednej strony może stać się zarówno miejscem ucieczki od narzuconego dzielenia przestrzeni, miejscem sprzyjającym refleksji i odpoczynkowi, z drugiej strony równolegle może wspierać procesy wspólnej pracy poprzez udostępnianie przestrzeni do co-workingu, jak to ma miejsce w niektórych bibliotekach akademickich (Lumley, 2014; Schopfel, Roche \& Hubert, 2015). Biblioteka funkcjonuje $\mathrm{w}$ tym kontekście nie tylko jako przestrzeń do pracy, ale także jako miejsce prowadzenia działań networkingowych nawiązywania kontaktów, wymiany doświadczeń, budowania zespołów i planowania interdyscyplinarnych projektów. 
W tym kontekście należy jednak rozstrzygnąć kwestię planowania proporcji przestrzeni pracy grupowej do przestrzeni pracy indywidualnej oraz praktyczne kwestie związane z podziałem (często niewielkiej) przestrzeni bibliotecznej między usługi dla użytkowników o różnych potrzebach. Istotne jest, by biblioteka $z$ jednej strony zapewniała użytkownikom możliwość integracji, a z drugiej jednak nie zaniedbywała użytkowników o odmiennych potrzebach, poszukujących okazji do indywidualnej lektury, nauki i pracy w bibliotece.

\section{EMERGING ADULTHOOD, CZYLI PRZEDŁUŻONE DORASTANIE}

Z punktu widzenia bibliotek tworzy się w wyniku rozwoju zjawiska emerging adulthood nowa grupa użytkowników sytuujących się wg ALA pomiędzy grupą $z w$. młodych dorosłych a dorosłymi (American..., 2018). Użytkownicy należący do tej kategorii są nastawieni na rozwój, ciekawi świata i spragnieni nowych wyzwań, z drugiej strony nie zawsze radzą sobie z organizacją pracy, podejmowaniem decyzji i wykonywaniem obowiązków. Potrzebują zatem od biblioteki stworzenia warunków do eksploracji własnych zainteresowań, ale też miejsca sprzyjającego podejmowaniu wyborów i wchodzeniu w dorosłość.

Użytkownicy należący do grupy emerging adulthood mogą korzystać z oferty projektowanej dla innych grup, szczególnie tej o charakterze edukacyjnym - warsztatów (np. artystycznych), kursów (np. komputerowych, językowych, pisania CV itp.), wystaw czy spotkań autorskich. Można się jednak zastanawiać, czy dla tej grupy, o specyficznych potrzebach, nie można zaprojektować usług o bardziej spersonalizowanym charakterze obejmującym działania kulturalne i edukacyjne połączone $z$ doradztwem zawodowym i zajęciami samorozwojowymi, np. z zakresu z zarządzania informacją czy organizacji czasu pracy. Takie rozwiązanie pomogłoby użytkownikom nie tylko rozwijać swoje zainteresowania, ale także racjonalnie planować działania, tak by ukierunkować się na wybór konkretnej ścieżki edukacji czy pracy.

\section{NOWE ZJAWISKA SPOŁECZNE A BIBLIOTEKI}

$\mathrm{Z}$ analizy wybranych nowych zjawisk społecznych w kontekście ich wpływu na działania bibliotek wyłaniają się wnioski, które mogą zaskakiwać.

Nie ulega wątpliwości, że współczesne biblioteki dążą do funkcjonowania jako tzw. "trzecie miejsce”, w którym ludzie realizują swoje pasje i ciekawie spędzają czas (Wrocławka \& Jerzyk-Wojtecka 2011). Biblioteki chcą zatem być postrzegane jako dynamiczne, nowoczesne instytucje wykorzystujące najnowsze technologie i zapewniające kreatywne środo- 
wisko do nauki, pracy czy rozrywki. Z analizy wytypowanych nurtów społecznych, takich jak unplugged, co-working czy co-living wyłania się jednak także alternatywna wizja biblioteki jako spa - miejsca odpoczynku od elektroniki, ale także azylu zapewniającego odpoczynek od gwaru związanego ze współdzieleniem przestrzeni nauki, pracy czy miejsca zamieszkania $\mathrm{z}$ innymi.

Te dwa obrazy biblioteki nie wykluczają się ani ze sobą nie konkuruja a jedynie pokazują złożony charakter potrzeb użytkowników bibliotek, którzy z jednej strony potrzebują stymulującego, nowoczesnego środowiska, a z drugiej niekiedy potrzebują także wyciszenia, odpoczynku i powrotu do elementów tradycyjnej kultury książki. Pokazuje to dualną naturę biblioteki, w której jest miejsce zarówno na nowoczesność, jak i na tradycję.

\section{WNIOSKI}

Zarówno w polskiej, jak i anglojęzycznej literaturze przedmiotu wątki sygnalizowane przez ALA jako istotne dla rozwoju bibliotek są rzadko poruszane. Analiza przeprowadzona w oparciu o materiały publikowane w serwisie WWW ALA oraz nieliczne publikacje naukowe $\mathrm{z}$ tego zakresu pozwala jednak sądzić, że omówione trendy społeczne mogą wpływać na potrzeby i przyzwyczajenia użytkowników, a tym samym na zakres i sposób świadczenia usług bibliotecznych.

Biblioteki jako instytucje usługowe działające w przestrzeni społecznej muszą monitorować nowe zjawiska kulturowe, ekonomiczne czy technologiczne i dostosowywać swój sposób działania do aktualnej sytuacji. Z przeprowadzonej analizy wyłania się interesujący obraz biblioteki jako miejsca oferującego zróżnicowane usługi - od tych wspierających nowoczesne technologie i innowacyjne rozwiązania do tych skupionych wokół tradycyjnych elementów kultury książki.

\section{BIBLIOGRAFIA}

American Library Association (2018). Centre for Future of Libraries - Trends [online], [dostęp: 10.10.18]. Dostępny w WWW: <http://www.ala.org/tools/future/ trends>

Chimczak, Przemysław (2017). Coliving. Mieszkania adresowane do generacji Y jako sposób na przyciaganie talentów [online], [dostęp: 14.11.18]. Dostępny w WWW: <http://2030.um.warszawa.pl/wp- content/uploads/2017/10/RAPORT-COLIVING_Przemys\%C5\%82aw-Chimczak.pdf>

Gmiterek, Grzegorz; Kotuła, Sebastian (2017). Aplikacje mobilne nie tylko w bibliotece. Warszawa: Wydaw. SBP.

Hollingsworth, Margaret. (2015). A quiet place for student veterans. Community College Journal of Research and Practice, vol. 39.11, pp. 1070-1073. 
Kuźma, Elżbieta (2015). Co może zaoferować biblioteka naukowa swoim czytelnikom w dobie wzrastającej komputeryzacji życia codziennego? W: Biblioteki bez użytkowników...? Diagnoza problemu: V Ogólnopolska Konferencja Naukowa, Supraśl, 14-16 września 2015. Praca zbiorowa pod red. H. Brzezińskiej-Stec i J. Żochowskiej. Białystok: Wydaw. Uniwersytetu w Białymstoku, s. 317-326.

Lumley, Risa M. (2014). A coworking project in the campus library: supporting and modeling entrepreneurial activity in the academic library. New Review of Academic Librarianship, vol. 20.1, pp. 49-65.

McVicker, Claudia. (2017). Last Child in the Library? A Survey of Use of E-books versus Traditional Books. Children and Libraries, vol. 15.4, pp. 4-7.

Schopfel, Joachim; Roche, Julien; Hubert, Gilles (2015). Co-working and innovation: new concepts for academic libraries and learning centres. New Library World, 116.1/2, pp. 67-78.

Schwartz, Seth J. (2016). Turning point for a turning point: Advancing emerging adulthood theory and research. Emerging Adulthood, vol. 4.5, pp. 307-317.

Wakaruk, Amanda; Truitt, Marc (2011). An Unplugged Space: Would your users value a gadget-free quiet zone in your library? [online], [dostęp: 11.12.18]. Dostępny w WWW: <https://era.library.ualberta.ca/items/41138dbf-b39c-43fd-981e-2 $17 \mathrm{~d} 5 \mathrm{~d} 1 \mathrm{~d} 7983>$

Wojciechowski, Jacek (2014). Biblioteki w nowym otoczeniu. Warszawa: Wydaw. SBP.

Wójcik, Magdalena (2013). Web 2.0 w działalności usługowej instytucji ksiażki. Kraków: WUJ.

Wójcik, Magdalena (2016). Najnowsze trendy w IT - potencjał dla bibliotek. Przeglad Biblioteczny, z. 4, s. 575-589.

Wrocławska, Maria; Jerzyk-Wojtecka, Justyna red. (2011). Biblioteka jako "trzecie miejsce" - międzynarodowa konferencja Biblioteki Uniwersytetu Eódzkiego: materiaty konferencyjne. Łódź: Wydaw. Uniwersytetu Łódzkiego.

Artykut po poprawkach wptynat do Redakcji 13 czerwca 2019 r. 
MAGDALENA WÓJCIK

Institute of Information Studies

Jagiellonian University

e-mail: magda.wojcik@uj.edu.pl

ORCID

\title{
UNPLUGGED - CO-WORKING - CO-LIVING - EMERGING ADULTHOOD? NEW SOCIAL PHENOMENA VERSUS LIBRARIES
}

KEYWORDS: Library users. Library services. Tasks of libraries. Social phenomena.

\begin{abstract}
Thesis/Objective - The author focuses on selected new social phenomena that, according to American Library Association (ALA), may have most advanced impact on library activities and future. The author intends to discuss consequences of those phenomena for library services. Research method - The analysis and critique of the literature was used as a research method. Based on publications from ALA web portal and search results obtained from such databases as National Library of Poland OPAC, WorldCat union catalog, LISTA abstracts, ELIS repository and selected multidisciplinary databases the current state of research on new social phenomena was defined from the library studies perspective. The documents analyzed were in Polish and English and were published in the years 2010-2018. Results - The analysis done by the author enabled her to discover that social trends indicated by ALA are rarely discussed by library studies specialists. Yet taking into consideration the contents of ALA web portal one may assume that those trends may have significant impact of the expectations of library users. Conclusions - The author concludes that the afore-mentioned social trends may influence library user needs and habits and, consequently, the scope and mode of delivering library services. Libraries as service institutions operating in social space have to monitor new cultural, economic and technological phenomena and adjust their mode of work to current situation.
\end{abstract}

